\title{
Nationalitet og kirke \\ i Danmark og Slesvig-Holsten 1770-1920 \\ med særligt henblik på Grundtvigs betydning
}

\author{
Af Anders Pontoppidan Thyssen
}

\section{Indledning}

Den afhandling, som hermed præsenteres, er i flere henseender beslægtet med en forgænger af Troels Fink, trykt 1952 med titlen Grundtvig og Sønderjylland (Jyske Samlinger 1952 s. 59ff). Det gælder især de overvejelser, hvormed den begynder, som stærkt betoner Grundtvigs betydning for den nationale udvikling i Sønderjylland. »Ingen enkeltmand i dansk åndsliv har haft større betydning for det danske Sønderjylland end Grundtvig«. Hans tanker havde »fra den nationale kamps første gry ... varmhjertede talsmænd i denne landsdel; hans højskoleidé fandt med oprettelsen af Rødding Højskole sin første virkeliggørelse her, og man kan næsten ikke forestille sig den nationale kamp efter 1864 uden den kraft, der kom nordfra gennem de grundtvigske højskoler.«

På den anden side måtte Fink tilføje nogle ord om det overraskende forhold, at Grundtvig ikke selv »hørte til dem, der gik i spidsen i Sønderjylland «. Men heroverfor betoner Fink igen, at Grundtvigs tanker dog fra første færd var blevet repræsenteret af dem, der straks tog kampen op; og den inddrog faktisk også Grundtvig fra 1840'rne.

Som helhed er disse synspunkter også efter min mening centrale for forståelsen af den dansk-slesvigske bevægelse. Men jeg har ikke kunnet følge Fink, når han på denne baggrund synes at konkludere, at hans opgave måtte begrænses til "Grundtvigs syn på spørgsmålene i Sønderjylland «. Jeg har snarere fundet det nødvendigt at udvide rammerne for at opnå et overblik over de forskellige nationale holdninger og deres forudsætninger, både på »dansk « og »tysk « side. De må give plads for alle faktorer af væsentlig betydning for den nationale udvikling, herunder ikke mindst Grundtvig og hovedtræk af det kirkelige liv. Det har faktisk vist sig, at der ofte har været et nært samspil mellem de nationale og de kirkelige bevægelser. Dette "program« vil af pladshensyn medføre forenklinger og udeladelser; men fordelen skulle være mere overskuelige oversigter over hovedlinierne. ${ }^{1}$ 
Det område, der inddrages, omfatter tre af det danske monarkis hovedlande til 1864, nemlig det egentlige Danmark eller »kongeriget« ( øerne og Nørrejylland til Kolding Fjord) og hertugdømmerne Slesvig og Holsten (fra Kolding Fjord til Elben). Om de andre »danske stater « som de blev kaldt, skal kun bemærkes, at Norge blev afstået 1814 og ikke vil blive omtalt i denne sammenhæng, og det samme gælder det lille hertugdømme Lauenburg, som kun forbigående fik tilknytning til monarkiet (1815-64). Hovedvægten vil blive lagt på kongeriget og det nordlige, overvejende dansktalende Slesvig (som nu kaldes Sønderjylland). Men hertugdømmerne Slesvig og Holsten spillede dog som helhed en vigtig rolle i udviklingsforløbet og kaster lys over både beslægtede og forskelligartede nationale og kirkelige reaktioner.

Administrativt var hertugdømmerne o. 1800 en enhed for sig. De havde fælles overordnet ledelse, der havde kontorer i København, men skønt de uofficielt kaldtes Tyske kancelli og virkelig talte tysk, fungerede de uden spændinger $\mathrm{i}$ forhold til de andre regeringskontorer. Tværtimod havde deres »direktører « ord for at kunne tale både tysk og dansk. Men derpå fulgte nogle vidtgående forandringer, som vi vil møde igen i det følgende.

De skyldtes i første række storpolitiske ændringer. I 1806 opløste den tysk- $\varnothing$ strigske kejser selv det ældgamle tysk-romerske rige, og den danske kronprins og regent, den senere Frederik VI, drog den konsekvens, at tiden var inde til at selvstændiggøre begge hertugdømmer

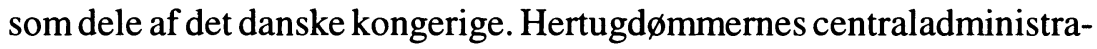
tion i København fik nu navnet »Det slesvig-holstenske kancelli«, og kronprinsen (nu kong Frederik) gik ind for, at dansk skulle være det danske riges hovedsprog og det officielle sprog i hele hertugdømmet Slesvig, forhandlinger, som skal omtales lidt nøjere nedenfor. Men kongens synspunkter vakte modstand, og denne modstand kan måske på langt sigt betragtes som grundlag for den egentligt national-politiske strid (fra 1815 og 1830).

Erhvervslivet stod som helhed på et noget højere stade i hertugdømmerne, når de sammenlignes med kongeriget. Det er svært at vurdere på grund af de skiftende betingelser; men nogle træk af befolkningsstatistikken fra o. 1840 er dog værd at nævne. Hertugdømmernes samlede folketal var da henved tre fjerdedele af kongerigets, men der boede 2500 pr. kvadratmil i hertugdømmerne mod kun 1855 i kongeriget. Befolkningstætheden var størst i Holsten, men hertugdømmet Slesvig overgik langt Nørrejylland med 2107 personer pr. 
kvadratmil mod kun 1215 i Nørrejylland. Hertugdømmerne overgik også kongeriget ved flere provinsbyer med forholdsvis mange indbyggere, således fire - Flensborg, Kiel, Slesvig og Rendsburg - med godt 10.000, hvortil kom Altona med 28.000. De største nørrejyske byer, Ålborg og Århus, havde kun ca. 7000 indbyggere. Sammenholdt hermed tyder de slesvig-holstenske tal faktisk på en ret betydelig byudvikling og befolkningsvækst.

Der er også grund til lidt nøjere omtale af landbrugsudviklingen i Nordslesvig, da den dansk-slesvigske bevægelse især byggede på den nordslesvigske bondestand. Udviklingen gik stort set samme vej som nord for Kongeåen, men mange steder tog bønderne initiativ til udskiftning af fællesjorden og tillige til indretning af bonde-børneskoler. Den egentlige reformtid begyndte som i kongeriget i 1760'erne med forordninger, der afsluttede udskiftningen, afløste hoveri og åbnede favorable muligheder for selvk $\varnothing b$ ved udstykning af krongodserne. Udviklingen begunstigedes af stigende landbrugspriser og driftsreformer og var i hovedsagen afsluttet inden pengekrisen i 1813 og landbrugskrisen i 1820 'rne. Derefter steg priserne igen og dermed velstanden, navnlig i 1840'rne.

Velstanden var dog især knyttet til de frugtbare egne i Østslesvig, hvor den kunne ytre sig i »finere « levevis og klædedragt og større afstand fra tjenestefolk og husmænd. På den mere magre jord i Vestslesvig var der jævnere skikke og mere lighed mellem gårdmændene og »den saakaldte Smaaestand «.

Til sidst nogle ord om hertugdømmernes forhold til kirke og skole. Først efter 1800 blev det almindeligt at fremhæve det kirkelige fællesskab mellem hertugdømmerne ved betegnelsen »landskirke«. Da kunne det begrundes historisk fx. ved en slesvig-holstensk kirkeforfatning, der blev vedtaget 1542 (svarende til den danske kirkeordinans af 1537). I virkeligheden blev kirkestyrelsen i de følgende århundreder grundigt delt som følge af hertugdømmernes opdeling mellem den danske konge og flere sidelinier. Men da det lille gottorpske hertugdømme i $1713 \mathrm{blev}$ inddraget under kongemagten, begyndte en samlingsproces, som førte til forening af hertugdømmernes kongelige dele under kronen.

Den »verdslige « og »gejstlige « magt kunne dog udmærket enes om at tilstræbe ensartede stiftskontrollerede kirke- og skoleordninger. Det gjaldt ikke mindst i J.G.C. Adlers lange tid som generalsuperintendent for Slesvig eller både for Slesvig og Holsten (1792-1834). »Nationalt « var han nærmest neutral, men han havde store organisatoriske evner og 
forstod at samarbejde både med Tyske kancelli og de to konsistorier (der fra 1834 blev afløst af den slesvig-holstenske regering). Som visitator virkede han for et ensartet statsskolevæsen ved indretning af ikke mindre end 450 distriktsskoler. Men han fik god st $\varnothing t t e$ i provstierne (der som regel tillige var amter). De blev ledet af provst og amtmand som et lokalt visitatorium, der skulle visitere alle sognene hvert år. Derved fik provstierne større indflydelse end i kongeriget - »som smaa fra hinanden afsondrede Stater«. Også præsterne fik talrige administrative opgaver vedrørende kirke-, skole- og fattigvæsen - ligesom i kongeriget på samme tid, men i Slesvig ofte i samarbejde med de gamle sogneråd.

De omtalte organisatoriske stramninger i Adlers tid kunne opfattes som rent praktiske reformer. Men heroverfor stod en række forhold, der ikke blev ændret, skønt de nok kunne indbyde til reformer. For det første hørte Ribe og en række »enklavesogne « syd for Ribe til kongeriget, mens en større del af Nordvestslesvig, der kaldtes Tørninglen, kun »kirkeligt «hørte til Ribe stift, men »verdsligt «til hertugdømmet Slesvig (og Haderslev vesteramt). På lignende måde hørte Ærø og Als (undtagen Sønderborg og Kegnæs) til Fyns stift, men udgjorde fra 1819 et særligt stift under dansk kirkelovgivning. Den slesvig-holstenske landskirke omfattede derfor kun fire provstier i Nordslesvig, to større: Haderslev og Tønder provstier, og to mindre: Sønderborg og ÅbenråLøgumkloster.

Hertil kom, at der fra gammel tid var dansk kirkesprog i Nordslesvigs landsogne, formodentlig af hensyn til folkesproget. Det blev også indført i de Adler'ske sogneskoler, og Adler synes o. 1800 at have accepteret en sproggrænse, der gik midt gennem Tønder provsti til Flensborg fjord. Men mange faktorer gjorde sig gældende, ikke kun hensyn til folkesproget. Skønt dette var overvejende dansk eller plattysk både i Nord- og Mellemslesvig, var hovedgudstjenesten i byerne altid tysk, og i Mellemslesvig holdtes kun enkelte danske gudstjenester. Det må også antages, at man i de ledende kirkelige kredse havde størst sympati for tysk uddannelse af præster og lærere. I hvert fald blev det i 1768 bestemt, at man kun kunne blive ansat som præst $i$ landskirken efter to års studium ved Kiels universitet, og i 1780'erne blev der oprettet to overvejende tysksprogede lærerseminarier, i Kiel (1781) og i Tønder (1786-88).

På den anden side havde det danske sprog en stærk støtte i selve den enevældige kongemagt, repræsenteret af kong Frederik VI (1808-39). I dec. 1810 erklærede han rent ud, at han »saasnart muligt« i hele her- 
tugdømmet Slesvig ønskede tysk erstattet af dansk i kirke, skole og retsvæsen, for dansk var dog det almindelige folkesprog. Dette blev derefter udmøntet af en række kongelige reskripter 1811-13, fx. omoprettelse af en universitetsstilling i Kiel for dansk sprog og litteratur, om ligeberettigelse af teologiske kandidater fra København og Kiel (trods bestemmelse af 1768, seovenfor), og attest om danskkundskaber for embedsans $\varnothing$ gere. ${ }^{2}$

Men kongen tav derefter, så han har formodentlig mødt modstand. Regeringens sprogpolitik forblev uklar i de nærmest følgende år, i hvert fald uden større forandringer i kirke og skole. Både dansk- og tyskuddannede præster og lærere kunne principielt finde ansættelse i Nordslesvig.

Kun én forandring skal dog nævnes, nemlig læreraspiranters voksende forkærlighed for kongerigske seminarier; men det havde for en stor del praktiske årsager: den danske læreruddannelse var både kortere og nyttigere for undervisning i dansktalende sogne.

Men disse forhold fører direkte ind i den nationale strid, og indledningen skal kun give et rids af dens forudsætninger. Som udgangspunkt skal dog tilføjes et afsnit om oplysningstiden, der fi,k stor betydning som grundlag for det 19 . århundredes nationale bevægelser.

\section{Oplysningstiden}

I årtierne efter 1770 spillede oplysningstidens mænd en dominerende rolle. De »oplyste « betragtede deres egen tidsalder som en enestående fremgangstid, præget af sund fornuft, politisk ro, økonomisk udvikling og vigtige reformer. Det enevældige styre fra 1660 var blevet et »oplyst enevælde«, der virkede for effektivitet i administration og økonomi og for mange slags reformer, især i landbrug og skolevæsen.

Reformerne fordrede et større og bedre uddannet korps af alle slags »embedsmænd «, og økonomisk fremgang skabte også en mellemstand af velstående byborgere og større landmænd. Disse sociale lag blev nu basis for en almindelig opvurdering af begrebet borger, kritisk vendt mod standsprivilegier, især adelens, der hidtil havde ført an. For tilhængere af oplysningen var tiden nu kommet til borgerne, »den tredje stand «, ikke gennem embeder i og for sig, men på grund af deres samfundsnyttige indsats. »Almenvellet «blev for så vidt et borgeranliggende. 
I de tre sidste årtier af det 18 . århundrede begunstigedes denne indstilling af vidtgående ytrings- og forsamlingsfrihed. Den nye borgerånd kunne derfor ytre sig gennem talrige tidsskrifter og småskrifter, oplysende, ræsonnerende og moraliserende om alle slags samfundsspørgsmål, og tillige gennem private institutioner som spindeskoler, oplysende søndagsskoler, sparekasser og lignende samfundsnyttige institutioner. $^{3}$

De bærende oplysningsidéer om naturret og frihed og lighed stammede fra samfundsfilosoffer i England, Frankrig og Tyskland. Men de havde også talrige talsmænd i den danske konges stater. Et godt eksempel er den lærde præst Henrich Ussing (1743-1820), hvis hovedværk »Kirkeforfatningen i de kongelige danske Stater « (6 bd., 1786-89) ikke blot behandler kirkeforfatningen, men også principielle spørgsmål vedrørende stat og samfundsordning. Her kan man få en grundig indføring i den tids tanker om stat og kirke, skrevet på letflydende dansk; men forholdet mellem tysk og dansk uddybes ikke. Ussing kan fx. stærkt anbefale brug af folkesproget i gudstjenesten, men kun som praktisk nødvendigt for forståelsen (se IV del, 1. bind § 273). Værket synes at have vakt en del opmærksomhed. Ussing fik flere subskribenter end ventet og mange »høie og ærede Navne« fra kongehuset og de højeste ministre til »alle Stænder«, især gejstlige og »borgere«, »selv et par Bønder var med «. ${ }^{4}$

Det nye hos Ussing bygger først og fremmest på naturretten, forstået som en fornuftstyret samfundsordning, hvis love tilsigter »Menneskenes fælles Fordele og Lyksaligheder «. Dermed afvises egentlig den bibelske »åbenbaring « som samfundsgrundlag. Men Ussing hævder dog, at åbenbaringen er klarere, og når han fremhæver udlandets store naturretslærere, tager han forbehold på dette punkt. »Havde de ikke pløiet med den christelige Aabenbarings Kalv, de havde neppe opløst saa vel Natur-Rettens mange mørke Taler«. (II, 137).

Den danske kongemagt skånes ikke for kritiske bemærkninger. »Ingen Fyrste i Verden er mere suveræn « end den danske, skriver Ussing; den danske konge påstås endog at være eneberettiget til at »forklare Loven « (II, 96, 142; det sidste iflg. Da. Lov 1-1-1). Men ingen kan anvende lovene uden fortolkning, og »en uindskrænket Monark, som vores, kan let forledes til en vis Grad af Tyrannie og sine Passioners Opfyldelse... til Undersaatternes Skade« (II, 114, 142f). Ussing må da også bekende, at han helst så monarkiet indskrænket »ved lidt Demokratie« som stænderforsamlingerne i Sverige; men da det havde 
lange udsigter, kunne han dog anbefale det milde danske monarki som den bedst mulige regeringsform (II, 111).

Overhovedet viste han på sin vis megen respekt for det bestående (jfr. II, 138f). Alle dele af »Kirkeforfatningen« blev indledet af blomstrende tilegnelser, det første bind til kronprins Frederik (den senere Frederik VI), det andet til dennes farbror arveprins Frederik, de følgende til de ledende medlemmer af regeringen og til alle biskopperne. Selve enevælden forsvarede han ved en udbredt dansk naturretsteori om folkets frivillige overdragelse af magten i Danmark til Frederik III i 1660; og Ussing betoner, at folket da alene var repræsenteret af gejstligheden og borgerne, ikke af adelen (II, 102). Men han foreslog faktisk en ny form for samarbejde mellem regering og befolkning ved fuld trykkefrihed og offentlig debat om vigtige love og forordninger. De burde offentligg øres som udkast, og »Publikum« ligefrem opfordres til at sige sin mening derom og belønnes for de bedste bidrag (II, 241-244). I det næste binds tilegnelse priste han udtrykkeligt statsrådets medlemmer »som beskytte Skrivefriheden - Dannemarks ædle Klenodie; som læse, og ere i Stand til at tænke over det Læste« (III, 1), og i det følgende bind takkede han varmt, fordi han anså sit forslag som fulgt ved $\mathrm{kgl}$. befaling om trykning af forhandlingerne $\mathrm{i}$ en ny tiendekommission (III, 2, 576). Det var i virkeligheden et hovedsynspunkt for hele hans værk, der på hvert titelblad lovede ikke blot at redegøre for kirkeforfatningen, men også for dens »Fordele og Mangler samt muelige Forbedringer «.

Med denne tankegang gik Ussing nærmest ind for det såkaldte »opinionsstyrede enevælde «, der byggede på samarbejde mellem kongemagten og de oplyste borgere ved fri offentlig debat. ${ }^{5}$ Det var også grundlaget for de to sider af oplysningsbevægelsen, som her har størst interesse: den nye patriotisk-demokratisk-nationale bevidsthed og de tilsvarende teologisk-kirkelige holdninger.

National bevidsthed kan have mange former, og deres motiver kan diskuteres. Men den »nationalisme«, der begyndte i Danmark i det 18. århundrede, var utvivlsomt især vendt imod indvandring fra Tyskland, som tiltog i antal og indflydelse. Siden middelalderen havde man i Danmark accepteret talrige tyske indvandrere, fx. som håndværkere, købmænd, adelige og lejesoldater. Hærens kommandosprog blev derfor 
tysk, og hofsproget overvejende tysk. Efter 1660 foretrak enevældens konger også tysk adel som mere pålidelig end den gamle danske. I 1699 var 20\% af Københavns indbyggere tysktalende, og der blev også talt meget tysk $\mathrm{i}$ en del provinsbyer. I den følgende tid (pietismens og Frederik V's tid, ca. 1700-1766) blev hoffet endnu mere tysksproget. Der blev derfor ansat mange fra Tyskland i de ledende embeder. Sidst i århundredet dannede den tyske overklasse i København en hel koloni, der foretrak landsmænd som medarbejdere og huslærere og indbød tyske kulturpersonligheder.

Dertil kom, at »tyskheden « havde solidt fodfæste i hertugdømmerne. Skønt folkesproget endnu var dansk i Nord- og Mellemslesvig, var tysk også her blevet administrationens og de dannedes sprog. I Holsten havde godsejerne dominerende indflydelse gennem et privilegeret »ridderskab « (især fra 1460), som også omfattede Slesvig. I byerne havde reformationen begunstiget højtysk som kirke- og skolesprog, og som handelssprog udbredtes både plat- og højtysk af indvandrede tyske købmænd og håndværkere. Økonomisk havde både Holsten og Slesvig større fremgang end kongeriget, landbrugs- og skolereformer kunne som helhed gennemføres hurtigere, og lovgivningen i det hele gradvis ensrettes. Mange lokale særordninger stod tilbage, men selv om kongetroskaben ikke blev anfægtet, var der allerede før 1800 tendenser til at opfatte hertugdømmerne som en enhed, et særligt tysksproget $» l a n d \ll .{ }^{4}$

Men samtidig opstod en bevidst dansk »offentlighed «, anført af universitetsfolk, embedsmænd og andre borgerlige intellektuelle. De hyldede oplysningen, der oprindelig var kosmopolitisk, men i Danmark fik den tidligt en vis dansk-patriotisk tendens. Det skyldtes ikke mindst Ludvig Holberg, der mest skrev på dansk (ikke latin og tysk) og gik stærkt ind for almindelig udvikling og brug af det danske sprog. Til sidst skænkede han endog sin formue til genoprettelse af Sorø Akademi (1747). Andre fulgte i samme spor, således lederne af Videnskabernes Selskab (fra 1742) og »Det danske Selskab til Fædrelandets Histories og Sprogs Forbedring « (fra 1745).

Men hvad skulle man stille op med de mange tyske indvandrere og embedsmænd? En ung dansk akademiker Tyge Rothe, der gennem højtstående tyske kredse havde fået tilknytning til kongehuset, gik ind for størst mulig åbenhed over for dygtige borgere i udlandet. I bogen Tanker om Kiarlighed til Faedernelandet (1759) hævdede han, at fædrelandet er det land, hvor man lever som nyttig borger, uanset fødested. Dermed byggede Rothe på en ny forståelse af ordet patriotisme: patriotisk er den 
borger, som virker for det almene bedste; og det gælder selv kongen, »den kronede Patriot «, der med rette åbner landet for dygtige »fremmede«.

Rothes bog kunne ikke glæde ikke danske kredse, der følte sig forbigået ved udnævnelser. I et skarpt modskrift påstod en danskfødt ung jurist, Eiler Hagerup, at netop fødestedet var afgørende. De indfødte havde »en mere naturlig Iver og Kierlighed til Fædrenelandet ", og der var mange kvalificerede blandt dem, både adelige og borgerlige, officerer, lærde og kunstnere.

Som disse eksempler viser, kunne der også opstå strid mellem »indfødte«, og modsætningerne mellem dansk og tysk skærpedes i høj grad af J.F. Struensees magtperiode 1770-72. Den blev præget af hans talrige reformer i oplysningens ånd, men mange af dem var så hensynsløse over for danske traditioner, at de vakte almindelig uvilje. Desuden repræsenterede Struensee »tyskheden « $\mathrm{i}$ dens mest arrogante form. Skønt født i Halle blev han politisk enerådende i København som den sindssyge konges læge og dronningens elsker. Derefter kunne han regere alle forhold ved »kabinetsordrer « på tysk, og dansk lærte han ikke. Den danske opposition reagerede ved offentlige angreb, som tvang Struensee til at indskrænke den trykkefrihed, han selv havde indført; og i januar 1772 sluttede hans regimente ved et kup, der førte til hans henrettelse.

De nye magthaveres kurs var danskorienteret og nærmest konservativ. De fleste at Struensees reformer blev ophævet, og allerede i februar 1772 blev statsrådet genoprettet med seks medlemmer, hvoraf fem var danskfødte. Samtidig indf $\varnothing r t e s$ dansk regerings- og administrationssprog, kun bortset fra det, der angik kongens »tyske provinser «; og få dage efter fik hæren dansk kommandosprog.

Men magten samledes efterhånden om Ove Guldberg (senere adlet som Høegh-Guldberg), der efter nogle år som professor i Sor ø blev nært knyttet til kongehuset, medvirkede ved Struensees fald og »arvede « hans anvendelse af kabinetsordrer (uden om statsrådet), som ikke var blevet afskaffet. Som god dansk patriot virkede han bl.a. for undervisning i dansk og fædrelandets historie (1775) og sørgede også for passende læreb $\emptyset$ ger. I dem kom Guldbergs patriotiske ånd til udtryk, ikke mindst $i$ en bog af Ove Malling »Store og gode Handlinger af Danske, Norske og Holstenere « (1777), hvor de vigtigste »dyder« er fædrelandskærlighed og kongetroskab. Men allerede titlen viser, at fædrelandet skulle omfatte alle kongens lande. 
At dette var Guldbergs opfattelse, fremgår af loven om indf $\phi d s r e t$, der fremkom som en kongelig ordre 1776, kun underskrevet af kongen og Guldberg. Den foreskrev, at »alle Embeder i Vore Stater « - militære og civile, store og små - herefter skulle forbeholdes »indfødte Landets Børn«.

Loven blev slået stort op som en ny grundlov og fejret ved tre tafler på Christiansborg. Hertil kom talrige mere borgerlige fester i København og danske provinsbyer - med taler af gejstlige, festmåltider, skåler, kanonsalutter, musik og dans. Både byfesterne og utallige hyldestskrifter viste, at loven i Danmark blev opfattet som en stor dansk-national gevinst, der især ville begunstige det danske borgerskab, skønt indfødsretten også omfattede hertugdømmerne. På den anden side opnåede Guldberg at knytte borgerskabets patriotisme nærmere til kongemagten og alle dens besiddelser som helhed.

Men også Guldberg-regeringen blev brat afbrudt, da kronprins Frederik 1784 blev myndig og foretrak at støtte sig til den »tyske« embedsoverklasse, der tidligere havde ført an.Til dem hørte i første række tre tysk-uddannede grever: A.P. Bernstorff og brødrene Chr. Ditlev og Ludvig Reventlow, som også blev foregangsmænd for landboreformer, de to Reventlow'er tillige ved oprettelse af skoler. Bernstorff, der også havde store fortjenester som »udenrigsminister «, blev nu den egentlige regeringsleder. Men denne kreds havde ingen sans for indf $\varnothing$ dsretten og en undersøgelse har vist, at Bernstorff fik ansat en hel »mafia « af slægtninge og tyskfødte venner i udenrigstjenesten og regeringskontorerne (1789). Dette bidrog formodentlig til, at den danskorienterede kritik udviklede sig til en hel »tyskerfejde«, især i årene 1789-90. De »danske« argumenter i denne strid gik kort sagt ud på, at tyskerne var fremmede, der gerne nød det danske brød, men ringeagtede dansk kultur og det danske sprog. Hertil kom nu, at også holstenerne skulle betragtes som tyskere, der burde holde sig til embeder i Holsten. Skønt svarene fra »tysk « side var få, medvirkede striden formodentlig til en fjendtlig stemning på begge sider. ${ }^{5}$

De kirkelige kredses forhold til denne udvikling må hovedsagelig belyses ved gejstlighedens reaktioner og begrænses til dens stilling til de vigtigste spørgsmål og begivenheder. Vedrørende forholdet til oplysningstidens samfundssyn kan der henvises til M. Bregnsbos afhandling 
(se note 5), der efter en omfattende undersøgelse af trykte prædikener konkluderer, at de $\mathrm{i}$ perioden $1750-1848$ præges af tiltagende afstandtagen fra tale om »den af Gud givne patriarkalske samfundsorden « til fordel for en »naturretligt baseret statsopfattelse « med menneskerettigheder og demokrati (især s. 337).

Det havde været nyttigt, om Bregnsbo nøjere havde omtalt præsternes stilling til nationale spørgsmål og fx. de mange tyske præster $\mathrm{i}$ København. ${ }^{6}$ Herom hører vi ikke meget, trods talrige citater fra tyske prædikener. Har der virkelig ikke været "patriotiske« elementer i prædikener før Struensees tid? Det skulle man dog formode i betragtning af gejstlighedens stærke reaktion mod Struensee. Hans fald 1772 vakte almindelig jubel i præstekredse. Ved en forordnet takkegudstjeneste lod ellers besindige præster »sig henrive til en lidenskabelig voldsomhed « i deres prædikener. ${ }^{7}$

Mange gejstlige medvirkede også i den næste begejstringsbølge, der skyldtes loven om indf $\varnothing$ dsret (1776). Ved de nationalt farvede byfester var det præster, der gjorde rede for lovens betydning. Således talte biskop C.M. Rottbøll i Viborg om de mange fremmede, der hidtil var blevet foretrukket af hoffet, hæren, kollegierne, handel, manufaktur og gesandtskaber, skønt de knap kendte fædrelandet og dets indbyggere. Hvad kunne der ikke ventes af et ædelt folk som det danske, »nu de atter komme til at føle sig som et Folk «. ${ }^{8}$

Navnlig i 1780'erne opstod tanker om en særlig dansk samfundsudvikling, anført af kongen (og kronprins Frederik), der fik æren af landboreformerne og andre fremskridt. Den danske konge var den milde landsfader, der kun virkede for fred og velfærd. Denne tankegang har formodentlig styrket nationalfølelsen. Hertil kom krigstrusler $0.1800 \mathrm{og}$ krigen mod england 1807-14, der fx. ifølge H.G. Clausen (kapellan og 1811 stiftsprovst ved Frue Kirke i København) gjorde »Fædrelandets Forsvar « til den vigtigste borgerdyd (1800). Den, der glemte sig selv til fordel for fædrelandet og dermed byrd og stand, kunne i stedet få den sande hæderstitel som »Borger og Fædrelandsforsvarer« (1801). Selv om Clausen fastholdt ordet borgersind, gav han det faktisk en ny farve som lig »Fædrelandskhed, Patriotismus og Fædrelandskjerlighed « (1813). ${ }^{9}$

Men det ser ud til, at danske praster som regel var utilbøjelige til at deltage i antityske angreb, og det kan hænge sammen med en vis respekt og sympati for tysk teologi. Både i Danmark og Slesvig-Holsten fik teologien efter 1770 et overvejende »rationalistisk« præg. Næsten 
alle synes dog at have anerkendt »religionens « nødvendighed for samfundsordningen, i det mindste som moralsk autoritet, men der var stadig strid om forholdet mellem fornuft og »åbenbaring«. De ældre, mere konservative lagde stadig stor vægt på åbenbaringen, dvs. den bibelskdogmatiske overlevering om arvesynd, forsoning, Jesu guddom og lignende, men de yngre kunne ikke forene disse »dogmer « med tidens fornuftstro og praktiske indstilling, som de gerne ville imødekomme.

Om disse spørgsmål var der meget at lære i Tyskland, og talrige dansk-nordiske studerende søgte til universitetet i Göttingen, hvor man også kunne gøre sig bekendt med den nye, historisk-filologiske bibelfortolkning. Blandt dem var Nicolai Edinger Balle, der selv gjorde så godt indtryk, at han fik tilbudt ansættelse som universitetslærer i Tyskland. Men han foretrak København, hvor han blev professor 1772 og biskop 1783. Også flere af hans universitetskolleger havde studeret $\mathrm{i}$ Tyskland, og byens tyske præster havde betydelig indflydelse, bl.a. som talsmænd for menneskerettighederne. En vis tyskorientering prægede desuden Chr. Bastholm, den mest ansete af byens danske præster. Hans forbillede var den tyske præst ved Petri kirke, B. Münter, og han begyndte som præst for en tysk menighed i Smyrna. Som præst i København fra 1772 blev han byens store »moderne« prædikant, der tilstræbte en let forståelig og retorisk elegant form, især om moralske spørgsmål, og i 1785 foreslog han gudstjenesten omformet efter samme princip. Dette blev dog bremset af Balle, der var mere konservativ og gjorde sig stærkt gældende, bl.a. som hovedforfatter af en ny, meget forenklet katekismus (autoriseret 1794) og ansvarlig for en ny, oplysningspræget salmebog (1798). Men Bastholm fik især betydning for mange unge præster, og det blev en af dem, L.N. Fallesen, der udgav Danmarks første teologiske tidsskrift (1793-1809). Det er her bemærkelsesværdigt, fordi det for en stor del bestod af oversættelser fra tysk. $^{10}$

Den samtidige teologiske udvikling i hertugd ømmerne var nært beslægtet. Den kan karakteriseres af to navne: J.A. Cramer og J.G.C. Adler. Cramer var moderat oplysningsteolog og i mange år tysk hofpræst i København. Men han fik især betydning som professor i Kiel 1774-88, hvor han reorganiserede universitetet og grundlagde et seminarium; desuden udarbejdede han en ny salmebog (1780) og en katekismus (1785). Adler blev generalsuperintendent for Slesvig 1792 og senere for begge hertugd ømmer (1806-34). Men han var født i Sydslesvig og havde indtil1792 virket i København, hvor han havde været professor i syrisk 
og tillige samlet mange som tysk prædikant (fra 1785). I København blev han påvirket af Bastholm, hvis plan om en gudstjenestereform han faktisk gennemførte ved en ny »agende « (liturgi), der blev godkendt 1797. Desuden gjorde han som tidligere nævnt en stor indsats for reform af almueskolevæsenet med oprettelse af 450 distriksskoler.

I 1790'erne blev der uro om oplysningsteologien. I København fremkom nu skrifter og blade med direkte angreb på både kristendom og præster, og Balle vakte opsigt ved at svare med offentlige bibellæsninger (fra 1793); da de blev trykt, meldte der sig 36.000 abonnenter. Regeringens reaktion var stærk begrænsning af trykkefriheden 1799. I Slesvig stift mødte Adlers agende så bred modstand, at indførelsen blev gjort afhængig af sogneafstemninger (1797-98). Derved blev den afvist af talrige landsogne.

Derefter ophørte den offentlige religionsdebat, som også blev overskygget af krigsforholdene 1801-14. Men oplysningens ånd overlevede dog både i præstekredse og i det oplyste borgerskab. Dermed var der også basis for tanker om national selvstændiggørelse. ${ }^{11}$

\section{Noter}

$1 \quad$ Fink har andetsteds skrevet mere udførligt om grænsekampens historie, især i de to værdifulde oversigtsværker »Rids af Sønderjyllands historie«, 1943, og »Geschichte des schleswigschen Grenzlandes«, 1958. - Jfr. til den følgende almindelige indledning A.P. Th.: Vækkelse, kirkefornyelse og nationalitetskamp i Sønderjylland (bd. VII af Vækkelsernes frembrud i Danmark) 1977, s. 15-25 med henvisninger.

$2 \quad$ Kongens stillling og sprogreskripter 1810-13 er udførligt omtalt af Knud Fabricius i Sønderjyllands historie IV, s. 55-62. Jfr. APTh 1977, s. 18-23 og 276-281 og sst. Kap. II.

Jfr. APTh 1977 s. $26 f$.

4 Ussing oplyser 1786, at han havde 915 subskribenter på værket, hvoraf 22 eksemplarer var tegnet af »Kongen, Dronningen, Kronprindsen og Arveprindsen«; Kirkeforfatningen I, Forerindring s. XXVII f (dronningen er formodentlig Frederik V's hustru Juliane Marie). - Vedr. Ussing og "Kirkeforfatningen « kan bl.a. henvises til den mere udførlige oversigt i H.J.H. Glædemark: Kirkeforfatningsspørgsmaalet i Danmark, 1949, s. 7-9, 18-26. 
$5 \quad$ Betegnelsen »Det opinionsstyrede enevælde«, der skyldes Jens Arup Seip (Hist. Tidsskr. (norsk), 1958-59), er efter min mening det vigtigste af enevælde-begreberne. De findes udførligt omtalt af Michael Bregnsbo i Samfundsorden og statsmagt set fra pradikestolen, Kbh. 1993, s. 237-67, der som helhed er en værdifuld unders $\emptyset$ gelse af ca. 10.000 trykte prædikener 1750-1848.

5 Forholdet mellem Dansk og Tysk er blevet udmærket belyst i Dansk identitetshistorie I-IV, red.af Ole Feldbæk, udg. 1991-92, der på mange punkter anlægger nye synspunkter. Dette værk har jeg derfor ofte benyttet, men dog med stærk begrænsning af de udvalgte træk og eksempler. Det foregående bygger især på Vibeke Winge: Dansk og tysk i 1700-tallet, bd. I, 89-103; Ole Feldbæk (om sprogpatriotismen) I, 112-130, samme (om T. Rothe) I, 130-142; samme (om E. Hagerup) I, 153-165; samme (om Struensee, Guldberg og indfødsretten) I, 165 218); Ole Feldbæk og Vibeke Winge (regeringsskiftet 1784) II, 26-29; samme (om tyskerfejden) II, 56-109.

6 Som de første, hvis prædikener gik ind for menneskerettigheder, nævner Bregnsbo (i anf. skr. s. 160-63) J.A. Cramer (1757), B. Münter (1766), H.F. Janson (1773) og J.C. Schønheyder (1772). Men han nævner ikke, at de alle havde tysk baggrund: de tre første var født i Tyskland (syd for Elben) og havde studeret der, og deres prædikener var tyske, da de selv var tyske præster i København. Schønheyder var søn af en tysk indvandrer og blev døbt og viet i Petri kirke (tysk), desuden havde han studeret i Göttingen. De fik i øvrigt alle fremragende karrierer.

7 Jfr. Bregnsbo s. 232-236, Bjørn Kornerup i Den danske kirkes historie V, 1951, s. 331-33. Kornerups fremstilling af oplysningstiden (sst. s. 232-505) er stadig den bedste fra et kirkehistorisk synspunkt.

Rottbølls tale iflg. Da.id.hist. I, 213-15; om de andre fester sst s. 200.

Jfr. M. Bregnsbo 1993 s. 240-42, 247 f., 328 f; om H.G. Clausen s. 149.

Jfr. Bj. Kornerup 1951 s. 354 (om Göttingen), 354-60 (Balle), 363-70, 474 (Bastholm.)

11 Om hertugdømmerne A.P.Th. 1977 s. 28-30; om 1790'erne Bj. Kornerup 1951 s. 444-446. 


\section{Voksende nationale spandinger ca. $1800-1848$}

Denne periode er i Danmarks og hertugdømmernes nationale historie de voksende spændingers tid. Trods megen debat om Dansk og Tysk i oplysningstiden havde begge parter indtil o. 1800 anerkendt den fælles kongemagt og statshelhed. Men derpå begyndte de modstridende nationale interesser at gøre sig gældende. Det førte i hertugdømmerne til kritik af den bestående helstat og fra 0.1840 til skarp strid mellem tysk- og dansksindede, der dannede grundlag for treårskrigen.

Udgangspunktet var monarkiets inddragelse i Napoleonskrigene (ca. 1801-14). Krigsforholdene medførte rustninger, indkaldelser og stadig større beskatning, og regeringen så herunder bort fra det slesvigholstenske ridderskabs traditionelle krav om skattefrihed. Det første urosignal kom derfor fra dette ridderskab, hvis leder Fritz Reventlow fra 1802 virkede for samling af de slesvig-holstenske godsejere. Målet var genindførelse af den slesvig-holstenske landdag (fungerede til 1712), der i praksis havde givet ridderskabet skattebevillingsret. Misstemningen tiltog 1806, da det tyske kejserrige blev opløst og den danske konge inkorporerede Holsten (hidtil et kejserligt len). Hertil kom »daniserende « love, der tilstræbte større ensartethed i helstaten, og især stærke finansielle indgreb i 1813, da regeringen indførte en ny mønt på basis af bankhæftelse i fast ejendom. Det ramte navnlig godsejerne og medførte en antidansk stemning i hertugdømmernes overklasse.

Efter fredsslutningen 1815 blev Reventlows bestræbelser forbundet med en slesvig-holstensk bevægelse på universitetet i Kiel. Baggrunden var almindelig begejstring $\mathrm{i}$ tyske universitetskredse for »frihed « og tysk enhed, med store forvetninger til det nydannede »tyske forbund « af alle tyske stater. De slesvig-holstenske perspektiver blev især fremhævet af den tyske historiker F.C. Dahlmann, der tillige blev ridderskabets sekretær (1815, professor i Kiel 1813-29). Her kom hans historiske studier til nytte. Problemet var, at det tyske forbund havde anerkendt Holsten som medlem, men ikke Slesvig, der ikke havde hørt til det tyske kejserrige. Heroverfor slog Dahlmann stærkt til lyd for slesvigholstenernes ret til en fælles forfatning som historisk anerkendt, især ved de fælles landdage og ridderskabets privilegier. Trods støttepetitioner fra slesvigske byråd lykkedes det ham ikke at gøre indtryk på Frederik VI, der lod sagen henlægge 1819, og Dahlmann appellerede også forgæves til den tyske forbundsdag (afvist 1823). Men han fik stor betydning for de slesvig-holstenske teorier. 
I 1830 opstod der atter uro, inspireret af revolutionen i Frankrig og andre lande. I Kiel kunne en yngre jurist Uwe Jens Lornsen, der havde haft tilknytning til Tyske kancelli, straks fremlægge et forfatningsforslag for hertugdømmerne: en fælles fri forfatning med et særligt lovgivende og skattebevilgende parlament. Desuden skulle hertugdømmernes »sløve « centraladministration i København effektiveres ved flytning til Kiel, og forbindelsen med kongen reduceres til en personalunion. Derved kom ren liberalisme til orde, som ikke lagde vægt på ridderskabet og debat om historiske rettigheder, men des mere på den borgerlige »tredie stand « som fremtidens bærende magt.

Lornsen fik en krank skæbne, da han efter fængselsstraf helt tabte modet og tog sit liv. Men Frederik VI tog faktisk hensyn til kritikken. Allerede 1831 bebudede han indførelse af stænderforsamlinger, en beskeden form for forfatning, der var indført i de førende tyske stater, og i 1834 forordnede han både en slesvig-holstensk »fællesregering « på Gottorp (ved byen Slesvig), en fælles slesvig-holstensk højesteret i Kiel og fire stænderforsamlinger: Jylland og øerne fik hver sin, og det samme gjaldt Slesvig og Holsten, som derved ligestilledes med danske provinser. De skulle kun mødes hvert andet år, og da valgbetingelserne fordrede ret betydelig grundejendom, begunstigedes godsejere og velstillede bønder, der blev anset for de mest besindige. Men det blev dog overvejende advokater, embedsmænd og lignende, som førte ordet.

Stændervalgene og forsamlingerne vakte bred politisk interesse og debat, til dels i nye blade. I de to første stænderforsamlinger (1835-38) var stemningen ret fredelig, om end med liberal tendens. Både $\mathrm{i}$ Danmark og hertugdømmerne kunne de fleste stænderdeputerede enes om at $\varnothing$ nske st $\varnothing$ rre trykkefrihed, offentlige statsregnskaber og styrkelse af stænderinstitutionen. Trods stort slesvig-holstensk flertal i de holstenske og slesvigske stænder var der egentlig ikke strid om nationale synspunkter, men endog personlig venskabelig kontakt mellem liberale førere i København og Slesvig-Holsten. Ved sin død i 1838 blev Lornsen ikke blot hyldet $\mathrm{i}$ hertugdømmerne, men også af liberale blade i København.

De nationale modsætninger var dog latent til stede, og i 1840'rne brød slesvigholstenerne stærkt igennem støttet af en fælles-tysk national bølge. Endnu i 1838 kunne de slesvigske stænders flertal st $\varnothing$ tte et forslag om dansk rets- og $\varnothing$ vrighedssprog i Nordslesvig, hvor kirke- og skolesproget var dansk, men i 1840, da den nye konge Christian VIII opfyldte dette $\emptyset$ nske ved et »sprogreskript«, mødte det voldsom 
modstand, især i de slesvigske stænder. Den dansksindede nordslesvigske befolkning vil blive nøjere omtalt i kapitel 4, men det må dog her nævnes, at den besvarede kongens reskript med en takadresse til kongen med næsten 3000 underskrifter. Men det vakte kun stærkere modstand i slesvigholstenske kredse, og ved det næste stændermøde i Slesvig 1842 tog deres repræsentanter direkte afstand fra helstatslige symboler. Til gengæld gik lederen af en lille dansk-orienteret stændergruppe, P.Hiort Lorenzen fra Haderslev, over til at tale dansk i stænderforsamlingen; men herimod protesterede ordstyreren og det store flertal i forsamlingen.

Denne episode fik stor betydning. I kongeriget blev Hiort Lorenzen hyldet på mange måder, ikke mindst af de liberale i København, der nu brød med de liberale i Kiel og blev »nationalliberale«, med krav om en fri fælles forfatning for Slesvig og kongeriget. De blev det førende parti i Danmark, styrket af de nationale møder og skandinaviske studenterfester. Også i Nordslesvig holdtes vigtige nationale møder, størst på Skamlingsbanken, der i 1843 samlede 6000, mest nordslesvigske bønder, og næsten 12000 i 1844 (iflg. samtidige skøn).

Men slesvig-holstenerne svarede med hele møderækker og vældig sang af talstærke kor. Og fra 1844 sluttede de sig sammen om et "landsparti «, der forenede Dahlmanns historiske retskrav med Lornsens forfatningskrav; desuden gik de nu ind for den augustenborgske hertugs krav om arveret til hertugdømmerne efter kronprins Frederik, der var barnløs. Da kongen i 1846 afviste denne specielle arveret i et »åbent brev«, slog den antidanske bølge igennem. Den holstenske stænderforsamlig vedtog kort efter en protest, som den sendte til det tyske forbund, og både den holstenske og slesvigske stænderforsamling sprængtes ved mandatnedlæggelser. Men de slesvigske stænder modtog også mange nordslesvigske adresser mod indlemmelse i Tyskland, og ved stændervalget i 1847 var der stor dansk fremgang. ${ }^{1}$

\section{Noter}

Perioden er udførligt belyst af Knud Fabrius i Sønderjyllands Historie IV (193337, s. 340ff). Kortfattet fremstilling af Troels Fink: Rids af Sønderjyllands historie (1955, 3. udg., s. 107-28). 


\section{Claus Harms og de kirkeligtsindede}

Som tidligere omtalt er det hensigten ikke blot at give en oversigt over den nationale udvikling, men at inddrage dens forhold til andre faktorer af kirkelig art. Det drejer sig især om to forskelligartede bevægelser: den kirkelige, der var inspireret af Harms og knyttet til Kiel og den slesvigholstenske landskirke (se kap. 3), og den grundtvigske, som var udpræget dansk og omfattede både »det kirkelige « og det »det folkelige« (se kap. 4).

Den kirkelige bevægelses store navn var Claus Harms (1778-1855), der i 1816 blev præst ved universitetskirken i Kiel ${ }^{1}$. Han havde da brudt med oplysningsteologien under påvirkning af tyske romantiskidealistiske strømninger og virkede med stor kraft som anti-rationalistisk vækkelsesprædikant. Skønt ikke strengt ortodoks blev han navnlig kendt for "95 teser« til reformationsjubilæet 1817, der ville »oversætte« Luthers lære til nutiden som modstykke til fornuftstroen. Hertil kom i Fr. Schleiermachers spor - en stærk betoning af præsteembedet og præstens opgave som forbillede og vejleder for menigheden. For de teologiske studenter, der samledes om ham i store tal, fik han især betydning ved pastoralteologiske foredrag, der gennemgik alle præstens opgaver og dermed kirkeordningen. Hans mål var åbenlyst at generobre landskirken for den lutherske tro, først og fremmest gennem gejstligheden.

Fra midt i 1830'rne blev det virkelig Harms' disciple og meningsfæller, de såkaldt »kirkeligtsindede«, der førte an i den slesvigholstenske landskirke. Den havde fra gammel tid større selvstændighed end den danske, bl.a. som ledet af Tyske Kancelli og ret selvstændige superintendenter og provster. Hertil kom kirkelige ordningstræk, der lignede de tysk-lutherske kirkers, og med Harms' meningsfæller som superintendenter og provster blev ordningerne strammet op, især ved grundige visitatser. De tolererede til en vis grad konventikler og kristelige foreninger, men foretrak et officielt og samlet kirkeligt arbejde; fx. ønskede de lokale ydre-missions foreninger indlemmet i en stor »nordtysk Missionsforening «. Alle reformer skulle udspringe af samarbejde mellem præsterne, der o. 1840 samledes i provstikonventer og fra 1845 også ved en årlig »Predigerconferenz« for hele landskirken. Hovedemnerne var udarbejdelse af en ny liturgi, katekismus og salmebog, hvor oplysningsteologiens spor skulle fjernes, og ikke mindst 
en helt ny selvstændig kirkeforfatning, som skulle samle og præge hele den slesvig-holstenske landskirke.

Dermed repræsenterede denne gejstlige fornyelsesbevægelse faktisk en kirkelig slesvig-holstenisme, og Harms havde selv haft nær tilknytning til lederne af den første slesvig-holstenske bølge til o. 1829. Senere tog både han og hans meningsfæller afstand fra den liberale slesvigholstenisme som en videreførelse af oplysningstidens verdslige og »selvrådige« indstilling. Lige til 1848 følte de sig på god luthersk vis forpligtet til troskab mod $\varnothing$ vrigheden og den danske konge. Men de kirkelige ledere fik dog nært samarbejde med de slesvig-holstenske politikere og embedsmænd, især i den slesvig-holstenske regering og de to stænderforsamlinger, den fælles højesteret (overkonsistorium) og et fælles eksamenskollegium. ${ }^{2}$

Den slesvigske generalsuperintendent C.F. Callisen var næsten med overalt, og hans stilling var typisk: På den ene side kongetro og helstatsloyal, på den anden side ivrig for reformer, der kunne styrke det kirkelige liv og udvikle landskirken til »et harmonisk hele«. Dette fordrede, mente Callisen, bl.a. udelukkelse af danskuddannede præster og lærere. Der var nok af teologer i Slesvig-Holsten, hvor 200 kandidater var ledige. Derfor burde det tysk-baserede seminarium i Tønder udvides, så alle børn kunne få tyskundervisning. Ifølge Callisen beroede interessen for det danske sprog kun på propaganda, som ville løsrive folket i Nordslesvig fra »ihr nächstes Vaterland «. ${ }^{3}$

Disse synspunkter blev kraftigt støttet af den slesvigske stænderforsamling, og de gjorde sig også gældende i provstierne. Som endnu et eksempel skal de lokale forhold i Tønder og Åbenrå provstier berøres. De omfattede den sydlige del af Nordslesvig og overskred i en del af Tønder provsti den traditionelle grænse for det danske kirke- og skolesprog i landsognene, der gik fra Flensborg fjord til Tønderegnen. Men trods det danske folkesprog var der ingen interesse for spørgsmålet og dansk identitet i hvert kun marginalt (iflg. provsterne). Derimod havde egnens kirkelige udvikling sat sig tydelige spor. En ældre pietistisk-herrnhutisk bølge var blevet grundigt fortrængt af oplysningstidens præster, men i $1830^{\prime}$ rne og $40^{\prime}$ 'me blev begge provstier stærkt præget af landskirkens kirkelige fornyelsesbevægelse, som vandt frem ved næsten alle præsteansættelser.

Det hang sammen med en i kongeriget ukendt ansættelsesordning. Amtmand og provst udvalgte tre af ansøgerne, og derpå fulgte 
menighedsafstemning efter prøveprædikener. Det var på denne tid en almindelig erfaring, at man i valgembeder foretrak »rettroende «præster, og det samme gjaldt $\mathrm{i}$ hvert fald de to provster. Både provst Mich. Ahlmann i Tønder (1830-52) og provst J.A. Rehhoff i Åbenrå (1837-50) var udpræget »kirkeligtsindede «. Harms-tilhængere, der udmærkede sig som energiske ledere og visitatorer. Også de foretrak »rettroende« ved præsteansættelser. De præster, der blev valgt, var overvejende yngre mænd, der havde studeret i Kiel og delte provsternes grundindstilling. If $\varnothing$ lge de kirkelige indberetninger fik de som regel god og ofte voksende kirke- og altergang.

For denne nye præstegeneration var det nærliggende at forbinde den landskirkelige reformbevægelse med slesvig-holstenske synspunkter. Menighedsvalg af præster blev opfattet som et slesvig-holstensk fortrin, da denne ordning var udbredt i hertugdømmerne undtagen i de traditionelt »kongelige« områder, fx. Haderslev provsti. Der var også andre undtagelser, men i de slesvigske stænder blev præstevalgordningen faktisk foreslået udvidet med Haderslev provsti. Den skulle befordre det gode forhold mellem menighed og præst, der skulle råde menigheden i »de fleste Sogneanliggender« (1844).

Vigtigere var dog for Tønder-Åbenrå-præsterne studierne i Kiel, hertugdømmernes kirkelige og nationale centrum. Allerede 1840 sendte langt de fleste præster i Tønder og Åbenrå provstier adresser til de slesvigske stænder om udelukkelse af danskuddannede fra præsteansættelse. I 1844 blev aktionen gentaget gennem en ny, skarpere adresse fra de samme præste-kredse, der udtrykkeligt henviste til den historiske forbindelse mellem hertugdømmerne. Ansættelsesordningen blev ikke ændret, men kampen for ændringer samlede de to provstiers præster (plus et mindre antal fra Haderslev Provsti) om slesvig-holstensk nationalpolitik, og de blev utvivlsomt støttet af de to provster, der i praksis - så vidt muligt - havde udelukket danskuddannede præster fra deres provstier og til dels også danskuddannede lærere ved store krav om tyskundervisning. For så vidt var de to provstier godt på vej mod »et harmonisk hele «! ${ }^{4}$

\section{Grundtvig og den folkelige Grundtvigianisme}

Den nærmeste danske parallel til Claus Harms var digterpræsten N.F.S. Grundtvig (1783-1872), der oprindelig blev kendt som talsmand for den 
gamle lutherdom, altså ligesom Harms og på omtrent samme tid. Men Grundtvig sluttede sig hverken til ortodoksien eller til Claus Harms' gejstlige reformbevægelse. Hans vigtigste kirkelige inspiration var den traditionstro gudstjeneste, hvis ritualer stort set var bevaret i kongeriget. Her fandt han »den historisk-kristelige tro « bevidnet, især af sakramenterne og den apostolske trosbekendelse ved dåben. Denne »kirkelige anskuelse « fremførte han polemisk mod rationalismen i skriftet »Kirkens Gienmæle« (1825).

Men modsat Harms' teser mødte Grundtvigs skrift næsten enstemmig fordømmelse $i$ hans eget land, hvor de fleste gejstlige stadig var oplysningsprægede; og det medf $\varnothing$ rte, at Grundtvig blev dømt for injurier og pålagt censur. Omtrent samtidig nedlagde han sit præsteembede. I stedet fik han - nærmest mod sin vilje - en vis tilknytning til forsamlingsbevægelsen, en dansk lægmandsvækkelse, der mødte megen modstand fra præster og verdslige myndigheder. Grundtvig måtte da forsvare de gudelige forsamlingsfolk som mere kristelige end de præster, der forfulgte dem; og fra 1832 holdt han selv en art frivilllige forsamlinger i København. Først i 1839 fik han atter en beskeden, men officiel ansættelse som præst ved Vartov hospital.

Denne situation dannede baggrund for et nyt syn på statskirken. Allerede i 1827 gik Grundtvig stærkt ind for fuld religionsfrihed ud fra det synspunkt, at både staten og den officielle kirke og gejstlighed måtte betragtes som sækulariserede; men ved religionsfrihed kunne de få "gammeldags troende « $\mathrm{i}$ det mindste samles under frikirkelige former. Nogle år efter begrænsede han dette til krav om frihed inden for statskirken som en neutral, verdslig ramme om forskellige trosformer, der skulle have lære- og ritualfrihed. Så kunne statskirken dog bevares som en fælles moralsk og pædagogisk ordning, der både omfattede rationalister og "gammeldags troende«.

Som følge heraf måtte Grundtvig søge et nyt fundament for samfund og stat, og det fandt han i den dansk-nordiske folkekultur med udgangspunkt $\mathrm{i}$ de oldnordiske og historiske studier, som han havde studeret i sin ungdom. Af romantikken havde han lært at opfatte historien som en helhed og folket som en åndelig sammenhæng, og $\mathrm{i}$ 1830'rne lagde han stor vægt på genoplivelse af folkets ånd til virksom indsats for »det fælles bedste«. Dette begreb kunne han uden forbehold overtage fra oplysningstidens patriotisme. Derved blev han på en måde selv oplysningsmand, da han navnlig gjorde sig til talsmand for en folkelig ungdomsh $\varnothing$ jskole, der skulle dyrke modersmålet og det dansk- 
nordiske menneskesyn siden hedensk tid og tillige give mere konkrete oplysninger om fædrelandets forhold. Højskoletanken rummede også en brod mod akademikere og embedsmænd som præget af fremmed tankegods, især den politiske liberalisme og den klassiske dannelse. I stedet satte Grundtvig sin lid til den enevældige konge og det almindelige jævne folk, der for størstedelen tilhørte bondestanden.

Med denne opfattelse kunne Grundtvig blive hovedordfører for det dansk-nationale; men det må ikke overses, at han stadig virkede som præst og i grunden håbede, at der både ville komme en kristelig og en folkelig vækkelse. I de yngre år kunne han ganske enkelt hævde, at »Alt, hvad der er Ædelt, Stort og Kraftigt i Mennesket, er en Guddomsvirkning «, og dette synspunkt fandt han både i kristendommen og i alle mytologier, især den nordiske (1824). Senere lagde han også vægt på forskellen: det jordiske fædreland er kun forgård til det himmelske, og folkeånden vil kun ledsage os til døren (1847). Men forgården var dog for Grundtvig vigtig nok, da den omfattede hans skoletanker og alt "folkeligt « arbejde, og med hans korte slagord: »Menneske først og kristen så« sattes forholdet mellem det kristelige og folkelige på plads: det menneskelige og folkelige skulle ikke for enhver pris kristeliggøres, men have sin egen ret, også fra et kristeligt synspunkt. Strengt taget skulle det folkelige altså komme først, mens forholdet til kristendommen skulle være fuldkommen frit. Som Grundtvig udtrykker det $\mathrm{i}$ en nytårsprædiken 1848: Kristi tjenere behøver kun at sige »Vaagn op« til folket »saa Kristus kan lyse for dig!... Vaagn op i hele den naturlige Følelse af Livets Sødhed, Modersmaalets Liflighed, Fædernelandets Deilighed! og afgiør da med dig selv, om du vil takke ham som opvakte dig «. ${ }^{5}$

Den »folkelige« Grundtvig kom egentlig først til udfoldelse med hans højskoleskrifter og taler i »Danske Samfund « i perioden 1835-47, der også affødte talrige andre foredrag og digte. Skelsættende var 51 foredrag i 1838 om den nyeste historie, som Grundtvig selv havde oplevet (trykt som Mands Minde 1877). De gjorde så stærkt indtryk, at Grundtvig straks fortsatte med en af ham selv oprettet foredragsforening, »Danske Samfund «. Den fik mange ulærde deltagere, for Grundtvig sigtede nu på at få jævne folk i tale og forsøgte sig frem med helt nye former. Talerne skulle veksle og ikke forelæse, men indlede samtaler; der skulle synges, en skik som fremkaldte en hel række visebøger med mange sange af Grundtvig og Ingemann; og der skulle holdes særlige fester på nationale mindedage. I de første år var det mest 
Grundtvig, der talte, og hans register spændte fra historisk-folkelige emner til aktuel debat - såsom stænderforhandlingerne og kravet om fri forfatning, skolespørgsmål og modermålets betydning. Men det var også Grundtvig man helst ville høre, for han havde en »ejendommeligt fængslende måde« at optræde på. »Det er ikke digtning, men hellere ikke ligefrem tiltale; det spiller i alle farver, lunefuldt skæmtende og i dybeste alvor, og det rev enhver med, hvis han ellers var modtagelig for åndelige indtryk.«(Fr. Hammerich).

Følgen var, at Grundtvig også blev efterspurgt som taler i andre foreninger, der blomstrede op i København i 1840'rne. Overalt gjorde han lykke som taler, ikke mindst ved Studenterforeningens skandinaviske møder. Men Danske Samfund fik særlig værdi for Grundtvig selv, der her fik afprøvet de undervisningsreformer, han forestillede sig i højskoleskrifterne. Derved fik disse møder grundlæggende betydning for grundtvigianismen som »folkelig« bevægelse. ${ }^{6}$

Uden for København blev Nordslesvig det første værksted for det grundtvigsk-folkelige eksperiment. Selv forholdt Grundtvig sig som tidligere berørt ret passivt til de slesvigske stridsspørgsmål til ind i 1840 'rne. De politisk-nationale anskuelser interesserede ham ikke meget, og de var indtil ca. 1840 snarere blevet fremf $\varnothing r t$ af slesvig-holstenerne end af dansksindede nordslesvigere. Kun én gang besøgte Grundtvig Nordslesvig, nemlig i 1844, da han talte på Skamlingsbanken. Men ved universitetet i Kiel havde han en energisk tilhænger i Chr. Flor, professor i dansk, som især havde sans for hans folkelige tanker. Sidst i 30'rne fik Flor nær kontakt med en lille danskorienteret kreds omkring Haderslev, anført af P.C. Koch, der »kun« var uddannet som købmand, men nu blev Flors nærmeste medarbejder. Interessen for Grundtvig var nærliggende i denne kreds, for selv på Haderslevegnen blev de der talte dansk ringeagtet af det bedre borgerskab og embedsmændene i Haderslev og godsejerne på landet. Men Grundtvig fremhævede just det danske modersmål og den danske fædrelandshistorie. Hertil kom Grundtvigs forkærlighed for bønderne og det jævne folk. Det var især dem, der talte dansk i Nordslesvig. Derfor var det fra begyndelsen »bondehæren«, Flor ville føre frem, og det lykkedes bedre for ham end for slesvig-holstenerne.

Der var måske også en sammenhæng mellem Grundtvigs virkeformer i Danske Samfund og den dansk-slesvigske bevægelses. Både i København og Nordslesvig gjaldt det om at få folk i tale. Det første og 
vigtigste danske organ, bladet Dannevirke, der blev udgivet af P.C. Koch fra 1838, skulle efter Flors og Kochs mening være fængslende læsning for jævne folk og derfor spænde vidt: - »som Discussionsblad, Avis, politisk Blad, Morskabslektüre, Adresseavis osv. «Noget lignende gjaldt det første møde på Skamling 1843 - planlagt af P.C. Koch - hvor der skulle »synges, tales, være Fugleskydning, Ringridning, Dands, Glædesild o.s.v.« Kort efter stiftedes »Den slesvigske Forening «, som blev ledet og præget af almindelige bønder, men især skulle virke for danske undervisningsanstalter i Nordslesvig. Det førte til oprettelsen af den første grundtvigske folkehøjskole i Rødding fra nov. 1844. Ifølge samtidige beretninger skulle der her være frie foredrag om historie, litteratur og landvæsen og i øvrigt være plads for »alt hvad der var livligt«: en sangforening, danseskole, komedier og et blad; og eleverne sang Marseillaisen, indf $\varnothing$ rte konstitution og ind $\varnothing$ vede parlamentariske bedrifter. Alt dette var naturligvis ikke foreskrevet af Grundtvig, men det, man tilstræbte, var åbenbart en fri, folkelig form. For så vidt kan disse bestræbelser forstås som en videreførelse af Grundtvigs i Danske Samfund. ${ }^{7}$

Områdemæssigt byggede den tidlige danske bevægelse på den nordlige og nordvestlige del af Nordslesvig, dvs. området nord og til dels vest for Tønder og Åbenrå provstier. Dermed blev den afhængig af de særegne kirkelige forhold i dette område. Den østlige del hørte til Haderslev provsti og dermed til landskirken, men som et af dens svageste led. Alle præsterne blev »kongeligt« kaldet på grundlag af anciennitet og eksamen (uden menighedsvalg). I 1830'rne var de fleste ældre præster rationalister, der kom i modsætningsforhold til en lægmandsvækkelse i dette årti.Vækkelsen bredte sig da i provstiets nordlige del, inspireret af brødremenigheden og den fynske forsamlingsbevægelse. På den tid var præsterne nationalt passive; men der var tradition for, at halvdelen skulle være uddannet i København, resten i Kiel (13 af i alt 26 i 1841), og det satte ondt blod. I 1840 støttede ni tyskuddannede præster fra Haderslev provsti præsteadressen fra Åbenrå provsti mod danskuddannede præster, og i 1844 underskrev elleve den skærpede adresse fra Åbenrå og Tønder provstier.

Derimod var størstedelen af provstiets lærere danskuddannede og sikkert danskorienterede. 16 af dem underskrev takadressen (1840), og 52 lærere og seminarister samledes $1844 \mathrm{i}$ Haderslev for at protestere mod forslag om udelukkelse af danskuddannede lærere. 
Men den vigtigste st $\varnothing t t e$ fik danskorienteringen af provstiets bønder. De blev ledet af forholdsvis velstillede gårdmænd, som var blevet politisk »vakt « af stænderinstitutionen og på en lang række punkter havde klaget over tilsidesættelse af bondestandens interesser. Vigtigst var kravet om afløsning af tiendeafgifterne, som stadig blev ydet i naturalier. Denne sag blev rejst for de slesvigske stænder både i 1836, 1838 og 1840 og medførte et skarpt modsætningsforhold til de kirkelige og verdslige embedsmænd. Sprogsagen indgik oprindelig i denne sammenhæng som et krav om, at embedsmændene skulle benytte befolkningens sprog. Men efter 1840 blev dette det store stridsspørgsmål, især ved Hiort Lorenzens demonstration for sprogenens ligeberettigelse i stænderforsamlingen. De slesvig-holstenske modangreb udviklede sig til en organiseret protestbevægelse, som begyndte i Haderslev, Tønder og Åbenrå og fik betydelig vægt, da kongen nu syntes imødekommende over for slesvig-holstenerne (184244). Men de byggede hovedsagelig på de tyskuddannede præsters sogne, og provstiets danskorienterede bønder lod sig ikke rokke. Det var især dem, der samledes om Den slesvigske Forening (ca. 300 af i alt henved 500 1843-47) og senere om periodens sidste store adresse fra danskslesvigsk side (med 36 indbydere fra Den slesvigske Forening af i alt 56). I foråret 1847 fik den henved 4000 underskrifter, der især tog klart afstand fra tilknytning til det tyske forbund. ${ }^{8}$

I nordvestområdet gik det anderledes. Den første sprogadresse fik ret bred tilslutning, fx. underskrev 1279 takadressen 1840 (823 i Haderslev provsti). Men mens striden derefter flammede op i Haderslev provsti, blev der forholdsvis roligt mod nordvest. Dette skyldtes sikkert i første række kirkelige forskelle. Det nordvestlige område bestod for størstedelen af det såkaldte Tørninglen (ca. 25 sogne ligesom Haderslev provsti), der i verdslig henseende hørte under Haderslev amt, men kirkeligt under Ribe stift, dvs. under dansk kirkestyre og kirkelovgivning. Hertil kom ca. 10 sogne langs vestkysten, som i alle henseender var kongerigske »enklaver «. Det betød, at både præster og skolelærere var ansat efter danske regler og dermed formentlig danskuddannede og dansksindede. Efter takadressen kunne man derfor her falde til ro. For sagen var, som en præst skrev, at vestboerne mindre følte det slesvigholstenske tryk end »vore Brødre østen for os« (H.P.G. Koch, Vodder 10/2 1843). 
Hertil kom stærk indflydelse af konservative antipolitiske vækkelseskredse i Nordvestslesvig, hvor både herrnhutismen og den fynske forsamlingsbevægelse fik et stort opsving o. 1840. De herrnhutiske kredses leder N.J. Holm fra Christiansfeld tog direkte afstand fra »Partiaand « og nationalpolitik, og forsamlingsbevægelsen havde samme indstilling. Dannevirkes redakt $\varnothing r$ P.C. Koch havde selv frigjort sig fra disse kredse, som han stammede fra, men hans bror J.B. Koch virkede som præst i Skærbæk (fra 1842) for fred og enighed mellem dansk- og tysktalende. Den første forstander for Rødding højskole J. Wegener følte sig i 1844 omgivet af modvillige religiøst-pietistiske bønder, og Chr. Flor måtte samme år - efter en rejse til Nordvestslesvig - konkludere, at »de christelig dansksindede Vestboer « var næsten døde for sprog- og nationalsagen og dermed vidt forskellige fra $» \emptyset$ stboerne $«$.

Men da var situationen allerede i forandring. Den vigtigste årsag var nok ansættelsen i årene 1835 - 43 af ca. ti unge præster langs vestkysten, der tilfældigvis alle var mere eller mindre grundtvigsk orienterede og derfor både kirkeligt og folkeligt aktive. De støttede Grundtvigs kamp for trosfrihed og forsamlingsfrihed, men delte også hans mistillid til pietistisk-herrnhutiske kredse. Ikke desto mindre fik de ofte god kontakt med vakte kredse.

Det gjaldt især Mjolden-præsten L.D. Hass (1835-40), som fik stor tilstrømning af forsamlingsfolk, deriblandt den fynske forsamlingsleder Peter Larsen Skrappenborg, der i disse år nærmede sig grundtvigianismen. En anden forsamlingsleder Chr. Kold (senere kendt som højskolemand) flyttede endog fra Mors til Mjolden, hvor han blev huslærer (1838) og Hass' nærmeste medarbejder. Her gik han offentligt ind for Grundtvigs folkelige syn, indførte ungdomsmøder med sang og oplæsning af Ingemann og arrangerede - efter»Danske Samfunds « mønster - en større fest for stænderforfatningens indførelse. I $1840 \mathrm{blev}$ han også hovedmand for en adresse mod ritualforandringer, svarende til en omfattende ritualadresse i kongeriget; men med 516 underskrifter fra ni sogne blev Kolds adresse den største samlede aktion for denne sag. Skønt den indledende erklæring var udpræget grundtvigsk, blev den kun forandret i neutral retning i to af de ni sogne.

Kolds ungdomsmøder og stænderfest blev videref $\varnothing \mathrm{rt}$ af $L$.C. Hagen, Hass's eftermand (1841-50). Udadtil optrådte Hagen ofte sammen med andre vestkystpræster, fx. slog de allerede i 1841 - 42 til lyd for oprettelse af en højskole i Nordvestslesvig, og i 1843 oprettede de en grundtvigsk ydremissions-forening for Tørninglen. Det må også nævnes, 
at stiftsbyen Ribe tidligt fik et dansk-nationalt præg, der bl.a. skyldtes en række grundtvigske præster. Den ytrede sig i byens blad, Ribe StiftsAvis, og ved »Danske Samfunds« møder. J. Wegeners kritik af Rødding højskoles omgivelser var i det mindste overdrevet; han havde ikke langt til Ribe, og i hans to nabosogne Lintrup-Hjerting virkede en ivrigt dansksindet præst P. Kragh (P.C. Kochs svoger), som i 1843 skaffede 57 indmeldelser i Den slesvigske Forening. Det førte til oprettelse af en »filial « og fra 1846 til store månedlige møder på Rødding højskole.

Disse træk er kun eksempler i korte rids. Men de peger dog klart på tiltagende indflydelse af grundtvigske præster i Nordvestslesvig. Derved blev der efterhånden plads for nogle af Grundtvigs folkelige tanker hos de »christelig dansksindede Vestboer . $^{9}$

\section{Noter}

1 Vedr. Harms kan henvises til Asger Nyholm, Sdj. Årbøger 1970, s. 1-86 og APTh 1977 s. 32-34.

$2 \quad$ Se APTh 1977 s. 32-54, 270-82.

$3 \quad$ Sst. APTh 1977 s. 102-107, 273f, 276-79, 281 f.

4

Se APTh 1977 s. 115-61, 294-304.

$5 \quad$ Jfr. A.P.Th.: Grundtvig og Spener, Grundtvigstudier 1967 2. $26 f$ (sidste citat); Grundtvigs tanker om kirke og folk, s. 84-114, 225-86, og Grundtvig og grundtvigianismen i nyt lys (udg. af Chr. Thodberg og A.P.Th. 1983, (citaterne s. 253f, 282f, 286, 350). Genoptrykt i A.P.Th.: Grundtvig og den grundtvigske arv, 1991).

Afsnittet om Danske Samfund er især inspireret af Fl. Lundgreen-Nielsens værdifulde afhandling om »Grundtvig og danskheden « (Dansk identitetshistorie bd 3, 1992, s. 9-187, om Da. Samfund s. 31-79, citatet af Hammerich s. 39). Jfr. A.P.Th. 1983 s. 269-74 (omtalt i note 1).

Se APTh 1977 s. 284-88.

Sst. s. 176-216, 308-30.

Sst. s. $217-65,330-45$. 


\section{Treårskrigen som slesvigholstensk kirkekamp}

Efter Christian VIII's åbne brev 1846 var forbindelserne mellem den danske regering og slesvig-holstenerne blevet afbrudt. ${ }^{1}$ Christian VIII arbejdede dog på en kompromisløsning, men da han døde i januar 1848, måtte han overlade denne opgave til sin søn Frederik VII. Kort efter tog begivenhederne fart under indflydelse af den franske februarrevolution samme år. Den bredte sig hurtigt til andre lande, ikke mindst til de tyske forbundsstater, overait som nationale og liberale rejsninger mod fyrsterne. Både i København, Kiel og Rendsburg samledes sidst i marts 1848 mere eller mindre truende folkeskarer, der krævede fri forfatning og national enhed, i København ved en fællesforfatning for kongeriget og hele Slesvig indtil Ejderen, i Kiel ved en slesvig-holstensk forfatning i tilslutning til det tyske forbund, hvor også Slesvig skulle optages.

I København stillede Frederik VII sig imødekommende til de danske krav, bl.a. ved løfte om en grundlovgivende forsamling, som dog foreløbig måtte begrænses til kongeriget. I Kiel kunne man hjælpe sig selv ved en provisorisk regering, forening af de to stænderforsamlinger, valg af en grundlovgivende »landsforsamling «, borgervæbning og rustninger. Alt dette kunne forstås som videreførelse af den slesvigholstenske bevægelse. Men begejstringen for den nye »altyske «samlingsbevægelse har dog utvivlsomt spillet en afgørende rolle i marts 1848. Den provisoriske regering proklamerede straks (24. marts), at den af al kraft ville tilslutte sig »Tysklands enheds- og frihedsbestræbelser «, og de så imponerende ud i foråret 1848: et »Vorparlament «allerede fra 31. marts, en folkevalgt nationalforsamling i Frankfurt fra 18. maj og en tysk »centralmagt « fra 28. juni, valgt af nationalforsamlingen.

De politiske omvæltninger inddrog imidlertid også forholdet mellem kirke og statsmagt, præster og befolkning, ikke mindst i hertugdømmet Slesvig. Alle præster var ved deres embedsed forpligtet til at støtte og opretholde kongens absolutte magt, og indtil 1848 var de fleste slesvigske præster faktisk politisk tilbageholdende eller konservative, uanset sympatier for slesvig-holstenismen. Det gjaldt også de Harmsprægede præster og Harms selv. Ganske vist hævdede han, at den lutherske religion ville »tale med om alt «, men hans egen politisk-religiøse tale var mest formaninger til lydighed mod $\emptyset$ vrigheden som en guddommelig ordning og advarsler mod »selvstyre « og overhovedet mod politiske folkemøder. Lignende synspunkter var af og til kommet til orde i Harmstilhængernes organ »Kirchen- und Schulblatt«, som i øvrigt ikke gav 
plads for politisk debat før i maj 1848. Og langt de fleste slesvigske præster omtalte den provisoriske regering med forbehold eller afstandtagen, da de i april 1848 (da Slesvig var besat af dansk militær) blev afkrævet en erklæring derom af en særlig kongelig kommission. Det gjaldt også generalsuperintendent C.F. Callisen, der udtalte, at han ganske vist havde anerkendt den provisoriske regering som værn om forbindelsen mellem Slesvig og Holsten, men nu havde bøjet sig for kongens ophævelse af den (30. marts) og som hidtil ville handle efter sin embedsed.

Over for konservative reaktioner som disse havde den provisoriske regering allerede ved sin proklamation gjort gældende, at den kun greb ind, fordi landsherrens vilje ikke længere var »fri«. Det betød, at man principielt ville opretholde både »landets « og fyrstens rettigheder. Og da det slesvigske-holstenske fællesskab beroede på historisk ret, var det ikke Kiel, men København, der havde gjort oprør for at tvinge kongen til at skille Slesvig fra Holsten!

Denne tankegang prægede også flere af svarene til den kongelige kommission. Men de viste også, at den provisoriske regering havde fremtrædende tilhængere blandt de slesvigske gejstlige, i første række provsterne J.A. Rehhoff, Åbenrå, og Nic. Nielsen, Slesvig by. Rehhoff var kendt som en dygtig provst og udpræget »kirkeligtsindet« slesvigholstener, Nielsen som den centrale skikkelse i de Harms' iske præsters reformbevægelse. Nielsens svar til den kongelige kommission var et energisk forsvar for den provisoriske regering og blev kort efter trykt. Det gjorde indtryk, og Nielsen blev derfor også udset til at forklare de slesvig-holstenske soldater, hvordan de skulle forstå deres troskabsed til den danske konge; den gjaldt, hævdede Nielsen, egentlig ikke kongen, men det slesvig-holstenske fædreland. Det var derfor betegnende, at C.F. Callisen blev afløst af Rehhoff som superintendent for Nordslesvig og Nielsen som superintendent for Sydslesvig (3. juli 48).

Kort efter gav også Harms slesvigholstenismen sin velsignelse ved at prædike, da »landsforsamlingen «åbnede. Ganske vist gentog han sine advarsler mod demokrati og folkesuverænitet, men der blev nok lagt mere mærke til, at han rent ud forsvarede den slesvig-holstenske folkerejsning som et nødvendigt nødværge mod en indtrængende røver (15. aug. 48). Forhandlingerne førte hurtigt til en meget liberal "statsgrundlov« (15. sept. 48), som ikke omtalte landskirken, men indførte fuld religionsfrihed - tilsyneladende uden strid, skønt landsforsamlingen 
talte mange præster og teologer. Den kirkelige bevægelse syntes dermed forenet med den nationale. ${ }^{2}$

Krigsbegivenhederne i foråret 1848 sluttede med en større preussisk fremrykning, efterfulgt af våbenstilstand 2. juli 48. Derpå fulgte langvarige forhandlinger om en våbenstilstandsregering. Resultatet blev en dansk regering for Als og Ærø og en nærmest slesvig-holstensk »fællesregering «, der 22. okt. 1848 formelt afløste den provisoriske regering, men reelt videreførte dens regimente til marts 1849 , hvorefter det blev fortsat af det såkaldte statholderskab, støttet af en preussisk ledet »forbundshær«.

Derved blev der tid til en stor debat om kirke og stat. På nationalforsamlingen i Frankfurt gik stærke kræfter ind for adskillelse af kirke, stat og skole; og den slesvig-holstenske grundlov foreskrev som nævnt kun religionsfrihed. Men unge præster og teologer lod sig ikke rokke i deres begejstring for de store forandringer, som fandt sted, og de forsvarede også adskillelse mellem kirke og stat, da det ville bane vej for en selvstændig kirkeforfatning med menighedsrepræsentation og forstærke fællesskabet mellem Slesvig og Holsten. Harms og hans ældre tilhængere var derimod meget betænkelige ved så revolutionære ændringer. Men den yngre radikale fløj vandt frem under debatten, der foreløbig endte med en stor »Predigerconferenz« $\mathrm{i}$ juni 1849. Her gik flertallet ind for en adresse til superintendenterne om snarest at udvirke et provisorisk kirkestyre, der snarest muligt skulle etablere en selvstændig kirkeforfatning.

Der blev også tid til konsolidering af slesvigholstenernes kirkelige indflydelse i Nordslesvig ved en betænksom ansættelsespolitik, der formodentlig især skyldtes Rehhoff. Mange præsteembeder var ledige efter flugt og afsættelse af danske præster, hvortil kom naturlig afgang ved død, pension o.l. 31 nyansættelser fandt sted i efteråret 48 og foråret 49 , langt de fleste i Nordslesvig. Og de nyansatte var som regel slesvigholstensk sindede og tysk uddannede mænd, ofte helt unge. For en sikkerheds skyld opgav man at indføre menighedsvalg (i stedet for kongelig udnævnelse) - skønt det var blevet anbefalet af de slesvigske stænder 1844 (maj 1848). Dette spørgsmål skulle nu afgøres af regeringen og omstændighederne i det pågældende pastorat.

I maj 1849 gik den slesvig-holstenske regering et stort skridt længere ved uden videre at indlemme Tørninglen i landskirken. Der var også andre tegn på radikalisering. Landsforsamlingen drøftede endog i 
juni 1849 direkte brud med kongen og opgivelse af teorien om den ufri hertug. $^{3}$

Men det fik ikke stor betydning, for på den tid var der opstået en ny politisk situation. Den tyske liberalisme var i opløsning, og det konservative Preussen ville ikke længere støtte slesvigholstenerne, men udvirkede 10. juli 1849 en ny våbenstilstand, der skulle være mere neutral end den første. Slesvig skulle styres i den danske konges navn af en preussisk og en dansk embedsmand, B.H. Eulenburg og F.F. Tillisch, om nødvendigt med en engelsk diplomat som mægler. Sydslesvig (incl. Tønder) skulle besættes af preussiske tropper, Nordslesvig (incl. Flenborgegnen) af svensk-norske, mens den slesvig-holstenske regering og hær skulle trækkes tilbage til Holsten.

Slesvigholstenerne svarede med stærke protester, der blev organiseret som "passiv modstand «, men nærmest anført af gejstligheden, især superintendent Nic. Nielsen og hans nærmeste kreds i og omkring Slesvig by. Allerede 22. aug. 1849 erklærede denne kreds, at de fortsat ville anse den slesvig-holstenske regering (»statholderskabet«) som deres rette $\emptyset$ vrighed og kun efter dens anvisning bøje sig for våbenstilstandskommissionen (der først blev indsat 25. august), sålænge den ikke krævede deres medvirken til adskillelse af Slesvig fra Holsten. Denne erklæring blev underskrevet af langt de fleste landskirkelige præster i Syd- og Nordslesvig, dog kun i moderat form af præsterne i Haderslev provsti. Men den blev også støttet af ca. 50 embedsmænd, overvejende verdslige (ved et møde i Slesvig by 29. aug.).

Den farligste modstander af denne politik var de kirkeligt konservative kredse i Berlin, der havde stor indflydelse på den preussiske konge. Kirkeligt havde de meget til fælles med Harms-præsterne, men politisk måtte Berlin-præsterne betragte dem som oprørere, præget af Frankfurtliberalismen. Nic. Nielsen kendte disse modstanderes magt og rejste i sept.-okt. 49 selv med en lille deputation til Berlin og den preussiske konge, og Harms sendte et personligt brev til ham. Denne trængte situation dannede baggrund for en række slesvigholstenske forsvarsskrifter.

Det gælder allerede forsvarspjecer i sept.-okt. 49, forfattet af Mich. Baumgarten, en ung præst i Slesvig by, senere professor. Det første, »Die Gewissensfrage der schleswigschen Beamten« (sept.), er en stærk appel til embedsmændene om at værne »landets « rettigheder, der var "givet af Gud «, men nu trues af »vore venner i Berlin«. Folket har ofret meget, men »vor bevægelse« er udgået fra embedsmændene, og det er 
nu deres sag at stå fast »på den hellige guddommelige grund « og vise, at Slesvig ikke kan forvaltes af våbenstilstandskommissionen.

Kort efter fandt Baumgarten et konkret angrebspunkt: at kommissionen 17. sept. 49 havde ophævet den provisoriske regerings kirkebøn for "vor fyrste «, der undgik at nævne kongen (13. maj 1848). Herom skrev han en lang pjece, der hævdede, at kirkebøn for kongen ville være en uberettiget politisk hyldest, da kongen kun var Slesvigs hertug. Og på udgivelsesdagen (10. okt.) enedes Baumgarten med et præstemøde i Slesvig by om en ny gejstlig protestadresse mod ændring af den "provisoriske « kirkebøn. Adressen blev tiltrådt af de fleste landskirkelige præster, dog modificeret og uden navne i Åbenrå og Haderslev provstier. Men denne debat rejste et videregående spørgsmål: kunne præsterne overhovedet forsvare at offentliggøre bekendtgørelser fra kommissionen? Det fremkaldte en ny, næsten samtidig adresse herimod, der i den endelige form udsendtes 17. okt. 1849. Men denne adresse fik kun bred tilslutning fra præsterne i Sydslesvig, formentlig fordi den indebar en direkte lydighedsnægtelse. Den fik ingen underskrifter fra Flensborg, Åbenrå og Haderslev provstier, og meget få fra Tønder provsti.

Forskellen mellem Nord-og Sydslesvig trådte dermed tydeligt frem. I Sydslesvig spillede præsterne på denne tid en betydelig rolle som talsmænd for slesvigholstenismen. Deres aktioner blev meget omtalt i tyske aviser og blade og medvirkede til at skabe en bred modstandsvilje, som ytrede sig i talrige lokale protestadresser, der fra sydslesvigske byer og amter. Men de omfattede også hårdhændede demonstrationer, fx. mod udsendinge fra våbenstilstandskommissionen. Allerede i efteråret 1849 var modstanden så omfattende i Sydslesvig, at kommissionen her måtte give op. ${ }^{4}$

\section{Nordslesvigsk folkerejsning under krigen}

I Nordslesvig medførte krigen store forandringer. Som omtalt var der i 1840'rne opstået en dansksindet bevægelse mange steder, især i Nordslesvigs landsogne; men det store flertal var indtil 1848 præget af en vis ubestemt slesvigsk konservatisme, der holdt fast ved de bestående slesvigske samfundsordninger. Nationalt indskrænkede mange sig til troskab mod kongen og den århundredgamle tilknytning både til kongeriget og Slesvig. 
Men denne holdning var i sig selv vidt forskellig fra slesvigholstenernes, hvis første mål var adskillelse af Slesvig fra Danmark, tilmed som led i et væbnet opgør med den danske konge og regering. Som følge heraf fremkaldte »oprøret« straks en bred modbevægelse i Nordslesvigs landbefolkning med store folkemøder, hyldestadresser til kongen og omfattende folkevæbning. På Ribeegnen skal 2000 bønder have været under våben allerede 28 . marts, og nogle uger efter omfattede denne bondehær hele vestkystområdet indtil Møgelt ønder. I midtlandet samledes 3-4000 bønder 3. april og organiserede stafetvagter fra Rødding til Burkal (ved Tønder). Den 14. april opgøres folkevæbningen til 7000 i Haderslev vesteramt og den sydlige del af østeramtet, og 2000 havde indtegnet sig i den nordlige del. På Als var der opstillet en organiseret landstorm på 18-1900 mand.

Væbningsbevægelsen blev støttet af Chr. Flor, men ledet af lokale kræfter med stænderdeputerede bønder og den slesvigske forenings førende mænd i spidsen. Også nye navne medvirkede, således H.A. Krüger, der var blevet den drivende kraft i midtlandet. Væbningsbevægelsen har nogle steder tydelige spor af de bondedemokratiske strømninger, som længe havde gjort sig gældende i Haderslev provsti (el. $\emptyset$ steramt). Flere »tysksindede« embedsmænd blev chikaneret eller arresteret, deriblandt nogle præster. En petition til kongen o. 20. april, der skal være forfattet af L. Skau, vendte sig mod det »mægtige Embedsaristokrati« som statsfjendtligt og undertrykkende over for bønderne. Befolkningen burde selv »regulere Forholdene « ved at vælge embedsmænd, der kunne fungere, til indfødte slesvigere havde den nødvendige uddannelse. Et folkevalgt amtsråd for Haderslev amt blev kun forhindret af preussisk besættelse, og på Als, der forblev under dansk kontrol, blev der virkelig etableret et »folkeråd «.

Mange nordslesvigske præster forholdt sig i april 1848 meget positivt til det dansk-folkelige røre. I Nordslesvig var det fire præster, der fra krigens begyndelse påtog sig at organisere indsamlinger af fornødenheder til den danske hær. På Als var den nyudnævnte biskop J $\phi$ rgen Hansen en ledende skikkelse, både kirkeligt og nationalt, og i det slesvig-holstensk dominerede Løgumkloster blev sognepræsten H.P.J. $H \phi c k e r$ samlingsmærket for den danske opposition. I Vestslesvig deltog flere præster personligt i folkevæbningen. Tre af dem var blandt hovedtalerne ved et væbningsmøde i Skærbæk 30. marts, og ved et nyt møde 7. april forelagde en præst udkast til en tillidsadresse til kongen, der derefter blev underskrevet af præsterne og godt 1300 lægfolk i 11 
sydvestlige sogne fra Skærbæk til Møgeltønder. De fleste af disse sogne havde hidtil været nationalt passive, især under indflydelse af brødremenigheden i Christiansfeld; men nu var selve brødremenigheden svækket af brydninger mellem den tyske ledelse og et stort flertal af dansksindede og dansktalende medlemmer 5 .

Folkevæbningens militære rolle var udspillet, da preussserne besatte Nordslesvig o. 1. maj 48. Ved denne indblanding fik preusserne faktisk afgørende betydning som grundlag for det slesvig-holstenske regime.

I begyndelsen søgte slesvig-holstenerne at vinde landbefolkningen. De tidligere danske blade blev forbudt, og »erstattet « af et nyt, dansksproget blad, "Nordslesvigske Tidende«, der forsikrede, at slesvigholstenerne hverken ville undertrykke landboerne eller det danske sprog (6. maj). Det blev også på den tid accepteret, at præster nægtede at publicere den provisoriske regerings forordninger med henvisning til, at de derved ville miste al indflydelse i deres menigheder. Publiceringen blev dog udtrykkeligt påbudt 20. maj, og snart efter begyndte opgøret med de dansksindede præster. Herunderfik Rehhoff, den nye superintendent,stor betydning. Han gav de dansksindede præster hovedskylden for befolkningens vaklende holdning og indirekte for væbningsbevægelsen, som ifølge Rehhoff var udtryk for gudløshed og kommunisme.

Om den nationale udvikling i Åbenrå amt til febr. 1849 foreligger en udf $\varnothing r l i g$ skildring, hvoraf nogle træk skal nævnes. Forfatteren var Jep Hansen, præst i Hjordkær, der nærmest var »slesviger«. Han var modstander af ejderpartiet, men endnu mere af tilslutning til Tyskland. Før krigen, skriver han, havde amtets landalmue været "ganske stille« og uafgjort, og slesvig-holstenerne havde bestemt ventet, at den ville følge dem. Men deres barske optræden under oprøret havde vakt modstand $i$ befolkningen. Endnu ved krigsudbruddet var bønderne i Hjordkær »ofte rådvilde«, men de havde søgt hans råd og næsten alle fulgt det. Selv havde han måttet flygte, og kun 8 havde deltaget $i$ valget af hans efterfølger, som fik ringe kirkegang og klagede over menighedens stivsind. Efter Jep Hansens mening havde den folkelige opposition hurtigt bredt sig på egnen, hvor der nu var færre slesvig-holstenere end i Haderslev amt. Hans vurdering st $\varnothing t t e s$ af adresser mod forening med Tyskland og adskillelse fra Danmark, der i oktober-november 1848 blev underskrevet af flere tusind østslesvigere, deraf 1294 i Haderslev amt, 2040 i Åbenrå amt, 1750 i Flensborg og 1226 på Flensborgegnen. Disse forskelle skyldtes dog måske politimæssige modforanstaltninger. 
Den 17. marts 49 fremkom i Nordslesvigsk Tidende en situationsvurdering, der på en måde viderefører Jep Hansens. Den var underskrevet af »samtlige Nordslesvigs Embedsmænd « som betænkning til den slesvig-holstenske regering, men overrasker ved at fremdrage en lang række vidnesbyrd om befolkningens danske sympatier. Disse sympatier havde medført, hedder det, at landbefolkningen i Nordslesvig havde sendt sine værnepligtige til den danske hær og desuden ladet sig organisere til landstorm mod de forventede tyske tropper. Tysksindede embedsmænd var under befolkningens bifald blevet bortført til Danmark, og andre slesvig-holstenere var blevet udsat for uafladelige plagerier. Valgene til den tyske nationalforsamling og landsforsamlingen havde i Nordslesvig samlet meget få, mens petitioner mod adskillelse fra Danmark fik talrige underskrifter. Mens kongens vilje gjaldt som »en hellig Lov«, havde befolkningen været uimodtagelig for den slesvigholstenske regerings befalinger, og denne holdning havde også vendt sig mod landskirkens præster.

Heroverfor kunne »embedsmændene« dog henvise til den slesvigholstenske stemning i Tønder, Åbenrå og Haderslev og til landbefolkningens forkærlighed for hertugdømmernes love, ret og mønt. Det var landalmuens autoritetstro og mangel på politisk dannelse, der havde gjort den til bytte for den danske propaganda og dansksindede præster og skolelærere. Den ville bøje sig for den stærkeres ret, og efter »Tysklands Fred med Danmark « ville de kunstige antipatier falde bort. Befolkningen havde altid udmærket sig ved »Agtelse for den høiere Villie«, og derfor ville den nok igen falde til føje.

Den officielle politik svarede hertil. I efteråret 1848 begyndte en hård kurs med tvangsinddrivning af skatter og gentagne klapjagter på værnepligtige. Det medførte bl.a. et blodigt sammenst $\varnothing$ d i jan. 1849, da en bondeskare ved $B r \phi n s$ blev angrebet af slesvig-holstenske tropper, en episode der i høj grad forstærkede modviljen mod det slesvig-holstenske styre. Nordslesvigerne blev mere og mere behandlet som fjender; men 6. juli 1849 slog danske styrker igen ved Fredericia, hvor den slesvigholstenske hær blev sprængt. ${ }^{6}$

Den anden våbenstilstand, der blev undertegnet 10. juli 1849 (gældende fra 25. aug. 49) var derfor et stort fremskridt for den dansksindede befolkning i Nordslesvig (indtil demarkationslinien fra syd om Flensborg til nord om Tønder). Den betød befrielse fra slesvig-holstenske gendarmer, skattekrav og jagt efter rekrutter; de flygtede kunne vende 
tilbage, og det samme gjaldt de danske blade. Als var fortsat dansk besat, og Tørninglen blev ført tilbage til Ribe stift.

Som tidligere omtalt foreskrev våbenstilstanden en foreløbig forvaltning af hertugdømmet Slesvig ved en preussisk og en dansk embedsmand, B.H. Eulenburg og F.F. Tillisch, med en engelsk diplomat som mægler. Da Sydslesvig blev besat af preussiske tropper, fik Eulenburg nærmest tilknytning til Sydslesvig. Men derved kom han i strid med den sydslesvigske gejstlighed, der var fuldt optaget af antidanske demonstrationer.

Følgen var, at kommissionen stort set opgav at gribe ind i Sydslesvig og i stedet rettede opmærksomheden mod Nordslesvig, som var besat af svensk-norske besættelsestropper, der sikrede kommissionens autoritet. Her var problemet de mange præsteafsættelser.før den anden våbenstilstand. Kommissionen havde svært ved at enes om generelle genansættelser af afskedigede embedsmænd, men et par konkrete ansøgninger om genansættelse blev dog imødekommet i nov. 49, da både Tillisch og kommissionens engelske medlem fandt, at afskedigelserne havde været uberettigede. Dermed var vejen fri for genansættelser, selv om de fordrede ophævelse af den fungerende præsts ansættelse, og hertil kom tiltagende enighed i kommissionen om nødvendigheden af afskedigelse ved direkte ulydighed mod dens beslutninger (i Nordslesvig!).

Alene i jan. 50 blev 7 gejstlige afsat, deriblandt H.P. Prahl, der var blevet provst for Haderslev provsti, og superintendent Rehhoff, Åbenrå, der begge blev afsat på grund af deres protester og modstand mod andre afskedigelser. Men nu blev de selv afløst af afsatte »danske « præster, hhv. U.S. Boesen som provst for Haderslev provsti og Jep Hansen som superintendent. Disse udskiftninger fremkaldte nye protester: 17 præster i Haderslev provsti sendte en protestskrivelse til Boesen, og 11 fra Åbenråegnen nægtede at anerkende Jep Hansen (heraf 3 ved supplerende erklæring); men kommissionen svarede nu kun med krav om loyalitetserklæringer, hvis de protesterende selv ville undgå afsættelse. Desuden søgte superintendent Nic. Nielsen (i jan.-febr. 49) at etablere en samlet protest fra de slesvigske præster, men den fik meget få underskrifter fra Nordslesvig, og Nielsen blev selv formelt afsat af kommissionen 8. april 1850 , skønt han reelt var i sikkerhed i Sydslesvig. Ved denne kurs fik kommissionen i alt afskediget ca. 20 præster i det nordlige Slesvig, og hertil kom 4 på Flensborgegnen. 
Den nordslesvigske befolkning blev i høj grad inddraget i kampen om embederne, som blev hovedemne for de dansksprogede blade og talrige sognemøder. For »Nordslesvigsk Tidende« var den anden våbenstilstand en »mørk Tid«, præget af kommissionens herredømme i Nordslesvig og »de i Almindelighed i Nordslesvig fremherskende danske Sympathier « (20. okt. 49). Men »Dannevirke « fik rigeligt stof fra sognedebatten og adresser om genansættelse af de »danske « præster og angreb på de fungerende. Kun i byerne fremkom forsvarsadresser for de slesvig-holstenske embedsmænd, men det kunne nu gå som i Åbenrå, hvor 438 borgere protesterede mod Rehhoffs afsked, men 730 takkede derfor; og ligeså i Haderslev, hvor $474 \mathrm{o}$. årsskiftet støttede den slesvigholstenske borgmester, mens $633 \emptyset$ nskede ham erstattet af den tidligere borgmester, der var kongetro. I hvert fald blev det klart, at den fortsatte kamp om embederne ikke styrkede slesvig-holstenernes stilling i den nordslesvigske befolkning. Snarere havde den afsløret et tydeligt skel mellem syd og nord omkring demarkationslinien.

Meget kunne nu tale for deling; men den overvejende stemning på begge sider krævede »hele Slesvig eller krig«. Krigen blev derfor genoptaget efter våbenstilstandens ophør 13. juli 50, dog uden Preussen, der havde sluttet fred 2. juli. Afgørelsen faldt allerede 25. juli, da den slesvig-holstenske hovedstyrke led nederlag (ved Isted nord for Slesvig by).

Dette betød i første række, at opgøret med de slesvig-holstenske embedsmænd kunne videreføres af den danske kommissær F.F. Tillisch, der efter krigen fik næsten uindskrænket magt i hele Slesvig. Det gik især ud over de sydslesvigske præster, der hidtil havde været beskyttet af preussisk militær. Ifølge en oversigt i Kirchen- und Schulblatt 5. april 1851 skulle våbenstilstandskommissionen og Tillisch siden nov. 1849 have fordrevet i alt 100 tysk-slesvigske præster, dvs. op imod halvdelen af præsterne i Slesvig stift. I slutningen af samme måned kunne Tillisch overgive det danske statsråd et forsvar mod angreb i hanseatiske og preussiske blade, der havde givet ham skylden for ubegrundede afskedigelser af 87 præster, 56 skolelærere og mere end 100 civilembedsmænd. Forsvaret bestod mest af de konkrete begrundelser for afskedigelserne, især vedrørende præsterne.

Disse talkan ikke forliges, og de er senere blevet anfægtet af andre unders $\emptyset$ gelser. Men der kan ikke være tvivl om, at kigstidens afskedigelser var store. Og de tyske og slesvig-holstenske tal har i sig selv inter- 
esse som baggrund for de følgende årtiers tyske angreb på det danske styre af hertugdømmet Slesvig. ${ }^{7}$

\section{Noter}

1 Kap. 5 er i hovedsagen et kort sammendrag af APTh 1977 s. 346-80, suppleret af Asger Nyholms store afhandling »Om Claus Harms«, i Sdj.Årb. 1970.

2 Jfr. om den kirkelige og den nationale bevægelse APTh 1977 s. 350-54, 363 (om Tørninglen); udførligere om svarene til regeringskommissionen i Nyholm: Slesvigske gejstlige og slesvig-holstenismen, 1980 s. 150-71, og om Harms' stilling Nyholm: Om Claus Harms, Sdj. Årb. 1970 s. 38-86.

3 Om kirkedebatten og præsteansættelserne APTh 1977 s. 354-58 og Nyholm 1980 s. 196-208.

4 Om "præstekrigen« i efteråret 1849 og foråret 1850 APTh 1977 s. 370-77; Nyholm 1980 s. 209-74.

5 Jfr om folkevæbningstiden APTh 1977 s. 359-362.

6 Jfr. om Jep Hansen, »embedsmændene« og den slesvigholstenske politik indtil sommeren 1849 APTh 1977 s. 359-70. Om folkeadresserne sst. s. 365.

7 Jfr. APTh 1977 s. 377-81. Genansættelser og afskedigelser efteråret fra 1849 til foråret 1851 er udførligt belyst af Nyholm 1980, især s. 275-360; (principper og omfang s. 355-60). 